\title{
About Artificial Intelligence: Robots and Philosophy
}

\author{
Hinzpeter J* \\ Medical Doctor, University of Chile, Clinical Hospital, Chile
}

*Corresponding author: Jaime Hinzpeter, M.D., Department of Traumatology, Clinical Hospital, University of Chile, Santos Dumont 999, Santiago Chile, Tel: 56-229788000; Email: jhinzpeter@hcuch.cl

\section{Editorial}

Volume 4 Issue 2

Received Date: February 25, 2019

Published Date: March 07, 2019

DOI: $10.23880 / \mathrm{ijbp}-16000148$

\section{Editorial}

Without a doubt, there is a lot of literature on the subject. That much progress has been made in terms of Artificial Intelligence in just a couple of years... as well. If we add numbers, we would say that more progress has been made than in the 50 previous years. Let us propose a name. The first one that comes to mind is mathematician Alan Turing who while philosophizing about a problem that seemed to go nowhere, ended up composed writings that would be the cornerstone of modern computer technology [1]. The Turing test, among others, is worthy of another article in itself. Currently, we find definitions of AI in indexed journals, publications printed on paper, social media and others obtained through search engines. Google Scholar, for example, led me to a definition that I liked and that dates back to 1987. All the efforts made in order to equip the computer systems with certain capacities are grouped under the term artificial intelligence [2]. Then, this brief article lists them: vision, recognition ... speech; human characteristics! The subject is fascinating and may even terrify you because, of course, conflicts arise parallel with developments, and potential risks are just around the corner. It is not that artificial intelligence opens a forbidden door a priori (if I may make a metaphysical analogy) but it poses a very important challenge, which is its proper development. Moreover, in the words of the Swedish philosopher and professor of the $U$ of Oxford Nick Bostrom, there are no opportunities for rehearsals and he adds: "I do not think we have a second chance [3]." This refers to the fact that there is only one opportunity to develop technology aligned with human values and civilization. The task of how to introduce an intelligent machine, complex concepts such as justice, kindness, and love, is already difficult, however, work is already being carried out on that. Many groups of scientists simultaneously collaborate with each other. According to the Swedish philosopher, this refers to the fact that work is being done on scalable control methods. What would Turing think of an intelligent machine? I believe his taciturn visage ${ }^{1}$ would have a great smile etched upon it. Let us leave these reflections for a moment and move on to the chronological existence of AI in the medical field.

Today, intelligent machines are very much present in medicine and will continue to be so. Dr. Jesús Moreno, doctor of the Spanish society of laparoscopic surgery and robotics says, "In ten years' time, robots in the operating room will be even more commonplace." 4 The modern history of robotic surgery [4] begins with the PUMA 560 $\left({ }^{\circ} \mathrm{r}\right)$ which evolved into two prototypes, PROBOT $\left({ }^{\circ} \mathrm{r}\right)$ and ROBODOC $\left({ }^{\circ} \mathrm{r}\right)$ used for prostatectomy and trauma surgery respectively. In 1994, we arrived at the digestive system field. The AESOP, an endoscopic system for abdominal surgeries, is basically a robotic arm that holds a laparoscopic camera. Near the end of the century, the ZEUS robot $\left({ }^{\circ} \mathrm{R}\right)$ was born, which extended the target to include urology. The Zeus robot is a large robot with three arms; a left arm and a right arm simulate the arms of the surgeon plus a third arm that an AESOP controls by voice. Its main difficulty was its size that made it difficult to use in an operating room. This is how the DA VINCI robotic surgery system $\left({ }^{\circ} \mathrm{r}\right)$ came about, consisting of three components: a visualization cart, the surgeon's console (arms with 7 ranges of movement and a computer system with 3D images) and the mobile cart (with more arms). This robot was developed by the SRI (Standford Research Institute) whose prototype was launched in 1997 [5] and approved, evidently, by the FDA. Its handicap, perhaps, is that it is still a large robot with many interconnections. 


\section{International Journal of Biochemistry \& Physiology}

During the 21st century, we have witnessed great developments in robotic surgery, both in models and sizes. In 2018, the Nature Journal of Biotechnology published that nanoscale robots will be used to fight cancer [6]. Promising results have been obtained in model animals, such as BAMA pigs, which show greater similarity with humans than rodents [7]. Amazing indeed.

Going back to the restlessness in the initial paragraphs, I ask myself whether machines will end up deciding what needs to be done, and who will do it ... In the near future, will more engineers than surgeons emerge from the medical profession?

Amazing too. (I would say downright terrifying)

The prologue of the Bioinformatics book by the biologist Rafael Lahoz-Beltran 2004, states:

The effects of technology on society will extend from the most common tasks such as home chores to commercial, social and political discussions [8].

What would Alan Turing say today? Or the writer Isaac Asimov?, who was far from the digital age when he published his book I Robot in 1950. His literary fiction challenged Turing's tests, but today's reality surpasses his stories. Both would be a witness today to artificial intelligence in all its dimensions and splendor, colonizing the system as digital assistants not only for cell phones, but for social networks such as Facebook, Microsoft, or Google as well [9]. Or also for evaluation and employment platforms (AURA system created by telephone).

Maybe there are only a few years left for them to become partners in daily life, algorithms, nanorobots, and virtual pets. Perhaps, as well, for the eradication of diseases such as cancer. But beware, Nick Bostrom in an interview this year emphasizes:

"You are creating something that would be very intelligent (the AI) and could also be very powerful. If we are not able to control it, we could give rise to the existence of a super intelligent system that could prioritize achieving its own values to the detriment of ours [10]. A couple of years ago, before this interview, the Swedish philosopher had already spoken of super intelligence... and says that something has not been answered yet: "superintelligence is an intellectual who is much smarter than the best human brains..." As a society-I wonder- How smart are we? You be the judge.

\section{References}

1. Jack B (2014) Biografía de Alan Turing; pionero de la era de la información-de. Descargado en elsitio eldiario.es.

2. de Mántaras RL (1987) Reflexiones sobre la inteligencia artificial. ARBOR 126(496): 131-142.

3. Bostrom N (2017) Suecia 195. Entrevista Revista RETINA. Madrid.

4. Valero R, Schatloff O, Ko YH, Chauhan S, Sivaraman A, et al. (2011) Robotic Surgery: History and Teaching Impact. Actas Urológicas Españolas 35(9).

5. (2007) Archivos especiales de urología 60: 4.

6. Li S, Jiang Q, Liu S, Zhang Y, Tian Y, et al. (2018) A DNA nanorobot functions as a cancer therapeutic in response to a molecular trigger in vivo. Nature Biotechnology 36: 258-264.

7. (2018) Revista Genética Médica News.

8. Beltra RL (2004) Bioinformática: Simulacion, vida artificial e inteligencia artificial.

9. Revista Harvard Deusto 2010.

10. Extracto de entrevista a Nick Bostrom en diario electrónico ABC cultura 2018. 